\title{
SISTEM PENDUKUNG KEPUTUSAN PEMILIHAN KARYAWAN TERBAIK PADA CV. EL GLORY MENGGUNAKAN METODE SAW
}

\author{
Kikye Martiwi Sukiakhy ${ }^{1}$, Cut Vita Rajiatul Jummi ${ }^{2}$, Anta Rini Utami ${ }^{3}$ \\ ${ }^{1}$ Jurusan Informatika, Universitas Syiah Kuala, Aceh \\ Email: kikye.martiwi.sukiakhy@unsyiah.ac.id \\ ${ }^{2}$ Jurusan Pendidikan Geografi, Universitas Syiah Kuala, Aceh \\ Email: cut.vita@unsyiah.ac.id \\ ${ }^{3}$ Fakultas Hukum Universitas Syiah Kuala, Aceh \\ Email: antariniutami@unsyiah.ac.id
}

\begin{abstract}
ABSTRAK
Kualitas sumber daya manusia adalah faktor penentu keberhasilan bisnis dari sebuah perusahaan. Dengan mempunyai sumber daya manusia yang baik maka suatu perusahaan dapat menjalankan proses bisnisnya dengan lancar serta sesuai dengan tujuan perusahaan. CV. El Glory merupakan salah satu perusahaan yang bergerak dibidang perdagangan barang dan jasa. CV. El Glory didirikan pada bulan Agustus tahun 2019. Dalam rangka mendorong terciptanya produktivitas kinerja yang terus meningkat, maka CV. El Glory melaksanakan pemilihan karyawan terbaik. Sistem pendukung keputusan dapat membantu pengambil keputusan untuk mendapatkan rekomendasi karyawan terbaik menggunakan metode SAW (Simple Additive Weighting). Pada penelitian ini data yang digunakan berasal dari data internal dan data eksternal. terdapat beberapa kriteria yang dibutuhkan dalam membantu pengambil keputusan untuk memilih karyawan terbaik, yaitu disiplin, kualitas pekerjaan, dan perilaku. Berdasarkan seluruh kriteria dan alternatif yang ada dalam penelitian ini menghasilkan Indah Lestari sebagai karyawan terbaik di CV. El Glory dengan total nilai preferensi yaitu 2,5. Metode SAW merupakan metode yang efektif serta praktis dalam perhitungan untuk menentukan rekomendasi karyawan terbaik di CV. El Glory sehingga pengambil keputusan dapat mempertimbangkan rekomendasi tersebut sesuai dengan prioritas yang ditentukan.
\end{abstract}

Kata Kunci: Sistem Pendukung Keputusan, Pemilihan, Karyawan, Terbaik; Simple Additive Weighting 


\section{ABSTRACT}

Islamic startups continue to experience development around the world. Sharia fintech lending itself that is currently established in Indonesia includes investment, syarQ, start zakat, paytren, and others. Until now, in Indonesia the majority of companies are still controlled by financial technology. In the official OJK website, as of June 2019, the data that has been described is that 46 financial service providers have received official OJK permission and 100 registered operators, along with the development of these fintech services, are gradually entering the Islamic financial system. The existence of the Sharia Supervisory Board which hinders the development of the sharia fintech lending industry has caused at least a few sharia fintech lending business operators in Indonesia. Paying attention to various aspects of rapid technological and economic development in Indonesia, the Indonesian Ulema Council (MUI) issued an opinion on public questions related to the existence of sharia-based product offerings from sharia business startups. This is done to provide an explanation of the various rules and provisions of technology-based financial services based on Islamic sharia.

Keyword: Artificial intelligence, fintech, syariah, MUI, OJK.

\section{PENDAHULUAN}

CV. El Glory salah satu perusahaan yang bergerak dibidang penjualan barang dan jasa yang didirikan pada tahun2019. CV. El Glory merupakan perusahaan swasta yang sedang berkembang dan mengutamakan kualitas dalam pengadaan alat - alat berat serta jasa perbaikannya. Sebuah perusahaan atau sebuah bisnis dapat berjalan dengan semestinya apabila didukung dengan adanya berbagai faktor, salah satunya adalah sumber daya manusia yang memiliki kualitas baik. Sumber daya manusia merupakan faktor penentu dibidang produksi, pembangunan atau bahkan kemajuan suatu perusahaan. Apabila sumber daya manusia yang dimiliki oleh suatu perusahaan memiliki kualitas yang kurang baik maka perusahaan akan sulit untuk dapat mencapai visi, misi, tujuan dan sasarannya. Sumber daya manusia harus mempunyai berbagai kompetensi yang dapat mendukung, mendorong serta dapat mempercepat terjadinya peningkatan produktivitas kinerja serta prestasi karyawan. Dalam rangka mewujudkan hal tersebut diperlukan adanya pemberian reward atau penghargaan kepada karyawan dengan harapan dapat memotivasi untuk bersikap lebih baik positif dan berkerja lebih baik. Oleh karena itu diperlukan sebuah sistem informasi yang dapat membantu pihak perusahaan agar mudah dalam memilih serta memutuskan siapa yang layak menjadi karyawan terbaik di CV. El Glory secara efektif yang sesuai dengan kriteria - kriteria tertentu.

Terdapat berbagai penelitian terdahulu yang terkait dengan penelitian yang akan dilakukan, salah satunya adalah penelitian yang peneliti kaji berjudul 'Sistem Pendukung Keputusan Pemilihan Karyawan Terbaik
Menggunakan Metode Analytical Hierarchy Proses (Studi Kasus Pada PT. Bando Indonesia)'. Pada penelitian tersebut menggunakan metode AHP dimana masing masing kriteria dan keputusan alternatif dibangdingkan antara satu dengan yang lain sehingga memberikan output berupa nilai intensitas prioritas yang memberikan penilaian terhadap kinerja karyawan yang berprestasi. [1] selain itu peneliti juga mengkaji penelitian terdahulu yang berjudul 'Sistem Rekomendasi Pemilihan Karyawan Terbaik Dengan Metode Topsis Pada Bussan Auto Finance'. Penelitian tersebut menggunakan metode Technique for Order Preference by Similarity to Ideal Solution (TOPSIS) yang merupakan salah satu metode yang digunakan dalam pengambilan keputusan dengan multi kriteria dimana alternatif yang terpilih harus memiliki jarak yang paling dekat dari solusi ideal positif dan memiliki jarak yang paling jauh dari solusi ideal negatif ditinjau dari sudut pandang geometris dengan tujuan menentukan kedekatan relatif dari suatu alternatif yang mempunyai solusi optimal. [2]

Penelitian ini mempunyai tujuan untuk mempermudah perusahaan dalam memilih karyawan terbaik yang sesuai dengan kriteria perusahaan. Melalui metode SAW (Simple Additive Weighting), permasalahan dalam memilih keryawan terbaik di CV. El Glory bisa terselesaikan sesuai dengan bobot preferensi serta rating kecocokan dan membandingkan semua rating alternatif yang ada serta dapat diteria lebih objektif dan sesuai dengan apa yang diharapkan.

\section{TINJAUAN PUSTAKA}


Salah satu bagian dari sistem informasi yang bisa dipergunakan dalam pengambilan keputusan serta mencari solusi terhadap suatu masalah adalah sistem pendukung keputusan yang juga berguna dalam meningkatkan efektifitas pada suatu proses pengambilan keputusan.[3] Sistem pendukung keputusan dapat melakukan evaluasi terhadap peluang yang ada. Sistem pendukung keputusan memberikan kemungkinan kepada para pengambil keputusan untuk dapat melakukan analisa melalui perangkat interaktif dengan menggunakan berbagai jenis model yang tersedia tetapi tidak mengotomasi setiap keputusan apapun.[4] Sistem pendukung keputusan mempunyai tujuan untuk memberikan berbagai alternatif keputusan yang lebih banyak serta lebih baik demi terciptanya peningkatan kemampuan para pengambil keputusan serta perumusan masalah yang sedang dihadapi sehingga dapat diambil keputusan yang tepat. Sistem pendukung keputusan tergolong ke dalam sistem permodelan, permanipulasian serta penyedia informasi. Fungsiya adalah membantu para pengambil keputusan baik dalam situasi yang terstruktur maupun dalam situasi yang semi terstruktur secara efisien pada saat dimana tidak satu orangpun mengetahui bagaimana cara mengambil keputusan yang sebenarnya.[5] manfaat sistem pendukung keputusan secara umum adalah untuk memperluas kemampuan para pengambilan keputusan dalam hal ini adalah pihak manajemen dalam melakukan pemrosesan data dan informasi bagi penggunanya. Sistem pendukung keputusan yang merupakan sebuah sistem berbasis komputer mempunyai komponen - komponen yaitu komponen knowledge (sistem pengetahuan), komponen language (sistem bahasa), serta komponen problem processing (sistem pemerosesan masalah) yang saling berinteraksi antara satu komponen dengan komponen yang lainnya. [6] Metode SAW atau juga yang dikenal dengan metode penjumlahan terbobot. Metode SAW memiliki konsep mencari penjumlahan terbobot rating kriteria pada masing - masing alternatif di semua tribut yang ada. Metode ini juga merupakan metode yang paling banyak dipergunakan dalam menghadapi situasi MADM (multi attribute decision making). MADM digunakan dalam mencari beberapa alternatif dengan menggunakan kriteria - kriteria tertentu sehingga dapat diperoleh alternatif yang optimal. [7]

\section{METODE PENELITIAN}

Pada penelitian ini data yang digunakan bersumber dari data eksternal maupun data internal. Data tersebut dikumpulkan dengan cara mencari data langsung ke lapangan serta dengan melakukan wawancara dengan para karyawan serta pihak manajemen perusahan CV. El Glory dan dilakukan juga studi literatur. Adapun 
kriteria - kriteria yang akan digunakan adalah

alternatif - alternatif yang akan dibandingkan.

Terdapat 6 (enam) alternatif dan 4 (empat)

kriteria yang akan digunakan melalui pembobotan fuzzy, kemudian data - data tersebut dianalisa sehingga memiliki sifat kuantitatif.

Ada berbagai macam metode yang bisa digunakan dalam sistem pendukung keputusan. Salah satunya dari metode -metode tersebut adalah metode SAW yang merupakan metode penjumlahan terbobot. Dalam metode SAW ini memerlukan proses normalisasi matriks keputusan ( $\mathrm{x}$ ) pada suatu skala yang bisa dibandingkan dengan semua rating yang ada, seperti yang dapat dilihat pada persamaan dibawah ini

$$
r_{i j}=\left\{\begin{array}{l}
\frac{x_{i j}}{\operatorname{Max} x_{i j}} \\
\frac{\operatorname{Min} x_{i j}}{x_{i j}}
\end{array}\right.
$$

Keterangan:

$\mathrm{r}_{\mathrm{ij}} \quad=$ nilai rating kinerja yang ternormalisasi

$\mathrm{x}_{\mathrm{ij}} \quad=$ nilai atribut yang dimiliki oleh setiap kriteria

$\operatorname{Max} \mathrm{x}_{\mathrm{ij}}=$ nilai terbesar yang dimiliki oleh setiap kriteria

Min $\mathrm{x}_{\mathrm{ij}}=$ nilai terkecil yang dimiliki oleh setiap kriteria

Dimana $r_{i j}$ yaitu rating kinerja yang ternormalisasi dari alternatif $A_{i}$ pada atribut $C_{j}$; $i$

$$
=1,2,3 \ldots, \mathrm{m} \text { dan } \mathrm{j}=1,2,3, \ldots, \mathrm{n}[8]
$$

Dalam penentuan nilai preferensi di setiap alternatif $\left(\mathrm{V}_{\mathrm{j}}\right)$ digunakan persamaan 2 berikut ini:

$$
\mathrm{v}_{\mathrm{i}}=\sum_{j=1}^{n} w_{j} r_{i j}
$$

Keterangan:

$\mathrm{V}_{\mathrm{i}} \quad=$ peringkat untuk setiap alternatif

$\mathrm{W}_{\mathrm{j}} \quad$ = nilai bobot untuk setiap alternatif

$\mathrm{r}_{\mathrm{ij}}=$ nilai rating kinerja yang ternormalisasi nilai $\mathrm{V}_{\mathrm{i}}$ yang bernilai paling besar artinya bahwa alternatif $A_{i}$ merupakan alternatif yang terbaik [9]

Berikut ini adalah diagram alir metode SAW:

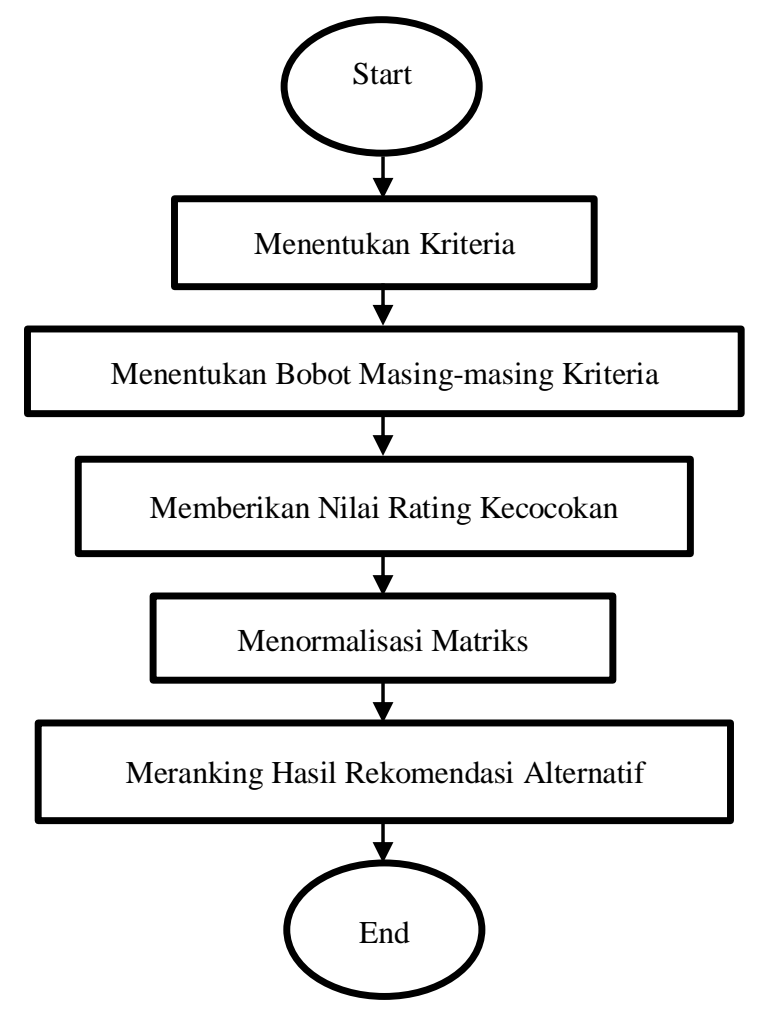

Gambar 1. Diagram alir metode SAW

berikut ini adalah langkah - langkah penyelesaian menggunakan metode SAW (Simple Additive Weighting) berdasarkan 
diagram alir metode SAW pada gambar 1 diatas,:

1. Pemberian nilai untuk masing - masing alternatif $\left(\mathrm{A}_{\mathrm{i}}\right)$ pada masing - masing kriteria $\left(\mathrm{C}_{\mathrm{j}}\right)$ yang telah ditentukan, dimana nilai $\mathrm{i}=1,2,3, \ldots, \mathrm{m} \quad$ dan $\mathrm{j}=1,2,3 \ldots, \mathrm{n}$.

2. Pemberian nilai bobot (W) untuk masing - masing kriteria yang dilakukan oleh pengambil keputusan.

3. Menghitung nilai rating kinerja yang ternormalisasi pada atribut $\mathrm{C}$ dari alternatif $A_{i}$ guna menornalisasi matriks

4. Proses penentuan peringkat dilakukan melalui perkalian antara nilai bobot preferensi dengan matriks yang ternormalisasi

5. Nilai prefensi ditentukan melalui penjumlahan hasil perkalian antara nilai bobot preferensi dengan matriks yang ternormalisasi

Penelitian ini dilakukan dengan cara menerapkan pendekatan multi attribute decision making (MADM). Pendekatan MADM ini digunakan untuk mencari beberapa alternatif yang mempunyai kriteria tertentu sehingga dapat menemukan alternatif yang optimal. Pendekatan MADM ini dapat dilakukan dengan dua langkah yaitu:

1. Melalui agresi alternatif - alternatif keputusan disetiap tujuan pada masing masing alternatif
2. Membuat peringkat alternatif - alternatif tersebut berdasarkan agregasi keputusan Penelitian ini mengambil 4 (empat) kriteria yang dipergunakan sebagai atribut pada proses mengolah data, antara lain kerjasama, kualitas pekerjaan dan perilaku. Hasil penelitian ini nantinya adalah informasi yang berupa rekomendasi karyawan terbaik yang akan diberikan kepada pihak manajemen sebagai bahan pertimbangan dalam mengambil keputusan pemilihan karyawan terbaik $\mathrm{CV}$. El Glory. Rekomendasi tersebut diberikan berdasarkan masukan yang telah diberikan oleh pengguna yang selanjutnya diproses dengan menggunakan metode SAW sampai diperoleh daftar rekomendasi karyawan terbaik

\section{HASIL PENELITIAN DAN PEMBAHASAN}

\subsection{Penentuan kriteria}

Pada penentuan karyawan terbaik dibutuhkan kriteria serta bobot pada metode SAW, tetapi dibutuhkan penentuan kriteria terlebih dahulu. Kriteria - kriteria tersebut didapat dari hasil observasi di CV. El Glory. Di bawah ini adalah kriteria serta alternatif yang telah diperoleh dalam penentuan karyawan terbaik, yaitu:

Tabel 1. Kriteria

\begin{tabular}{|lll|}
\hline No. & \multicolumn{1}{c|}{ Kriteria } \\
\hline 1 & C1 & Disiplin \\
\hline 2 & C2 & Kualitas Pekerjaan \\
\hline 3 & C3 & Perilaku \\
\hline
\end{tabular}

Tabel 2. Alternatif

\begin{tabular}{|lll|}
\hline No. & & Alternatif \\
\hline 1 & A1 & Andriansyah \\
\hline
\end{tabular}




\begin{tabular}{|llc|}
\hline 2 & A2 & Putri Clara \\
\hline 3 & A3 & Indah Lestari \\
\hline 4 & A4 & Junaidi \\
\hline
\end{tabular}

Pada bobot kriteria terdiri dari 5 (lima) bilangan Fuzzy yang terdapat pada tabel berikut ini:

Tabel 3. Bilangan Fuzzy

\begin{tabular}{|lccc|}
\hline No. & Bobot & Keterangan & Linguistic \\
\hline 1 & 0 & sangat rendah & SR \\
\hline 2 & 0.25 & rendah & R \\
\hline 3 & 0.5 & sedang & S \\
\hline 4 & 0.75 & tinggi & T \\
\hline 5 & 1 & sangat tinggi & ST \\
\hline
\end{tabular}

\section{2 penentuan bobot pada masing - masing}

kriteria

Terdapat 2 (dua) pembobotan yang dipakai sebagai bobot preferensi (w) pada sistem ini yaitu, pembobotan tingkat kepentingan sdan pembobotan tingkat kecocokan yang terdapat pada masing - masing alternatif. Pembobotan tingkat kecocokan bertujuan untuk dapat mempermudah dalam pengolahan data serta masing - masing data yang selanjutnya dikonversikan kedalam bentuk fuzzy.

Di bawah ini adalah pembobotan untuk setiap kriteria C1, C2, C3, C4,-- Disiplin, Kualitas Pekerjaan, Kerjasama, Perilaku

Tabel 4. Nilai pembobotan

\begin{tabular}{|lcc|}
\hline No. & Nilai & Keterangan \\
\hline 1 & 0 & Sangat tidak baik \\
\hline 2 & 0.25 & Tidak baik \\
\hline 3 & 0.5 & Cukup baik \\
\hline 4 & 0.75 & Baik \\
\hline 5 & 1 & Sangat baik \\
\hline
\end{tabular}

\subsection{Memberikan nilai rating kecocokan}

Setelah semua kriteria ditentukan, proses selanjutnya yaitu dengan melakukan pencocokan nilai dari setiap alternatif berdasarkan kriteria. Dari karyawan - karyawan tersebut akan dipilih menjadi satu karyawan terbaik, data alternatif dapat dilihat di bawah ini:

Tabel 5. Nilai rating kecocokan

\begin{tabular}{|cccc|}
\hline \multirow{2}{*}{ Alternatif } & \multicolumn{3}{c|}{ Kriteria } \\
\cline { 2 - 4 } & C1 & C2 & C3 \\
\hline A1 & Baik & Baik & Baik \\
\hline A2 & Sangat Baik & Baik & Baik \\
\hline A3 & Sangat Baik & Sangat Baik & Baik \\
\hline A4 & Sangat Baik & Baik & Sangat \\
\hline
\end{tabular}

Tabel 6 berikut ini merupakan matriks keputusan $\mathrm{x}$ yang terbentuk berdasarkan tabel diatas selanjutnya dikonversi kedalam bilangan fuzzy

Tabel 6. Rating kecocokan alternatif pada kriteria

\begin{tabular}{|cccc|}
\hline Alternatif & \multicolumn{3}{c|}{ Kriteria } \\
\cline { 2 - 4 } & $\mathrm{C} 1$ & $\mathrm{C} 2$ & $\mathrm{C} 3$ \\
\hline $\mathrm{A} 1$ & 0,75 & 0,75 & 0,75 \\
\hline $\mathrm{A} 2$ & 1 & 0,75 & 0,75 \\
\hline $\mathrm{A} 3$ & 1 & 1 & 0,75 \\
\hline A4 & 1 & 0,75 & 1 \\
\hline
\end{tabular}

\subsection{Normalisasi Matriks}

Dalam menormalisasi matriks, maka digunakan data pada tabel 6 dengan tujuan untuk memperoleh hasil perhitungan pada masing - masing kriteria, sebagai berikut:

1. Kriteria disiplin $(\mathrm{C} 1)$

$$
\begin{aligned}
r_{11} & =\frac{0,75}{\max (0,75 ; 1 ; 0,75 ; 1)} \\
& =\frac{0,75}{1}=0,75 \\
r_{12} & =\frac{1}{\max (0,75 ; 1 ; 0,75 ; 1)} \\
& =\frac{1}{1}=1 \\
r_{13} & =\frac{1}{\max (0,75 ; 1 ; 0,75 ; 1)} \\
& =\frac{1}{1}=1 \\
r_{14} & =\frac{1}{\max (0,75 ; 1 ; 0,75 ; 1)} \\
& =\frac{1}{1}=1
\end{aligned}
$$

2. Kriteria Kualitas Pekerjaan (C2) 


$$
\begin{aligned}
\mathrm{r}_{11} & =\frac{0,75}{\max (0,75 ; 0,75 ; 1 ; 0,75)} \\
& =\frac{0,75}{1}=0,75 \\
\mathrm{r}_{12} & =\frac{0,75}{\max (0,75 ; 0,75 ; 1 ; 0,75)} \\
& =\frac{0,75}{1}=0,75 \\
& =\frac{0,75}{1}=0,75 \\
\mathrm{r}_{13} & =\frac{1}{\max (0,75 ; 0,75 ; 1 ; 0,75)} \\
& =\frac{1}{1}=1 \\
\mathrm{r}_{14} & =\frac{0,75}{\max (0,75 ; 0,75 ; 1 ; 0,75)} \\
& =\frac{0,75}{1}=0,75
\end{aligned}
$$

3. Kriteria Perilaku (C3)

$$
\begin{aligned}
\mathrm{r}_{11} & =\frac{1}{\max (1 ; 1 ; 0,75 ; 0,75)} \\
& =\frac{1}{1}=1 \\
\mathrm{r}_{12} & =\frac{1}{\max (1 ; 1 ; 0,75 ; 0,75)} \\
& =\frac{1}{1}=1 \\
\mathrm{r}_{13} & =\frac{1}{\max (1 ; 1 ; 0,75 ; 0,75)} \\
& =\frac{1}{1}=1 \\
\mathrm{r}_{14} & =\frac{0,75}{\max (1 ; 1 ; 0,75 ; 0,75)} \\
& =\frac{0,75}{1}=0,75
\end{aligned}
$$

hasil perhitungan dari setiap kriteria dapat dilihat pada tabel 7 berikut ini

Tabel 7. Matriks ternormalisasi

\begin{tabular}{|cccc|}
\hline Alternatif & \multicolumn{3}{c|}{ Kriteria } \\
\cline { 2 - 4 } & $\mathrm{C} 1$ & $\mathrm{C} 2$ & $\mathrm{C} 3$ \\
\hline $\mathrm{A} 1$ & 0,75 & 0,75 & 0,75 \\
\hline $\mathrm{A} 2$ & 1 & 0,75 & 0,75 \\
\hline $\mathrm{A} 3$ & 1 & 1 & 0,75 \\
\hline $\mathrm{A} 4$ & 1 & 0,75 & 1 \\
\hline
\end{tabular}

\subsection{Melakukan rangking hasil rekomendasi alternatif}

Ditahap berikut ini hasil dari perkalian matriks yang ternormalisasi selanjutnya dijumlahkan dengan nilai bobot. Kemudian dilakukan ranking yang berdasarkan hasil dari perhitungan tersebut. Rekomendasi terbaik dalam pengambilan keputusan merupakan alternatif yang mempunyai nilai yang tertinggi. Tingkat kepentingan pada setiap kriteria merupakan landasan pihak manajemen dalam memberikan bobot

$\mathrm{W}=0,5 ; 1 ; 1$

Kemudian dilakukan persamaan 2 dan menjumlahkan hasil perkalian tersebut dengan tujuan memperoleh rekomendasi alternatif yang paling baik

$$
\begin{aligned}
& V_{1}=(0,5 \times 0,75)+(1 \times 0,75)+(1 \times 1)=2,125 \\
& V_{2}=(0,5 \times 1)+(1 \times 0,75)+(1 \times 1)=2,25 \\
& V_{3}=(0,5 \times 1)+(1 \times 1)+(1 \times 1)=2,5
\end{aligned}
$$

$\mathrm{V}_{4}=(0,5 \times 1)+(1 \times 0,75)+(1 \times 1)=2,25$

Hasil perhitungan peringkat di atas bisa dilihat pada tabel 8 di bawah ini. Hasil perhitungan dengan nilai $\mathrm{V}_{3}$ yang paling besar adalah alternatif $\mathrm{A}_{3}$ yang merupakan alternatif terbaik. Sesuai dengan data yang didapatkan dari tabel $8, \mathrm{~V}_{3}$ memperoleh nilai terbesar yaitu Indah Lestari. Hal ini sebagai indikasi bahwa Indah Lestari bisa direkomendasikan sebagai karyawan terbaik di CV. El Glory.

Tabel 8. Nilai prefensi total

\begin{tabular}{|ccccc|}
\hline Alternatif & \multicolumn{3}{c}{ Kriteria } & $\begin{array}{c}\text { Hasil } \\
\text { Akhir }\end{array}$ \\
\cline { 2 - 5 } & $\mathrm{C} 1$ & $\mathrm{C} 2$ & $\mathrm{C} 3$ & \\
\hline $\mathrm{A} 1$ & 0,75 & 0,75 & 0,75 & 2,5 \\
\hline
\end{tabular}




\begin{tabular}{|ccccc|}
\hline A2 & 1 & 0,75 & 0,75 & 2,625 \\
\hline A3 & 1 & 1 & 0,75 & 2,875 \\
\hline A5 & 1 & 0,75 & 0,75 & 2,37 \\
\hline
\end{tabular}

menentukan karyawan terbaik di CV. El Glory. Berdasarkan semua kriteria dan alternatif yang

\section{SIMPULAN}

Dalam sistem pendukung keputusan, metode SAW dapat dipergunakan untuk membantu memilih karyawan terbaik. Data data yang terdapat dalam penelitian ini bersifat dinamis baik data kriteria maupundata subkriteria yang artinya data tersebut dapat diganti kapan saja sesuai dengan apa yang dibutuhkan oleh pengambil keputusan. Kriteria orientasi pelayanan merupakan kriteria yang memiliki kontribusi yang paling besar dalam ada dalam penelitian ini menghasilkan Indah Lestari sebagai karyawan terbaik di CV. El Glory dengan total nilai yaitu 2,5. Metode SAW merupakan metode yang efektif serta praktis dalam perhitungan untuk menentukan rekomendasi karyawan terbaik di CV. El Glory sehingga pengambil keputusan dapat mempertimbangkan rekomendasi tersebut sesuai dengan prioritas yang ditentukan.

\section{DAFTAR PUSTAKA}

M. Hasanudin, Y. Marli, and B. Hendriawan, "Sistem Pendukung Keputusan Pemilihan Karyawan Terbaik Menggunakan Metode Analytical Hierarchy Process ( Studi Kasus Pada Pt . Bando Indonesia )," Semin. Nas. Teknol. Inf. dan Multimed. 2018, vol. 6, no. 3, pp. 91-96, 2018.

J. Informatika and U. Pamulang, "Issn 2541-1004," vol. 1, no. 1, pp. 12-16, 2016.

T. Murti, L. A. Abdillah, and M. Sobri, "Pinjaman Dengan Metode Fuzzy Tsukamoto," Semin. Nas. Inov. dan Tren 2015, 2015.

M. K. Kusrini, "Konsep Dan Aplikasi Sistem Pendukung Keputusan,” Penerbit Andi. 2007.

E. Turban, J. Aronson, and T. Llang, Decision Support Systems and Intelligent Systems. 2003.

S. Dedi, A. Pardede, A. Harahap, A. Putera, and U. Siahaan, "Sistem Pendukung Keputusan Pemilihan Peserta Jaminan Kesehatan Masyarakat ( Jamkesmas ) Menerapkan Metode MOORA,”vol. 2, no. 2, pp. 16-22, 2018.

I. Bukori, P. Pujiono, and S. Suharnawi, "Metode Simple Additive Weighting (Saw) Untuk Penentuan Peringkat Dalam Pembuatan Peta Tematik Daerah Rawan Demam Berdarah Dengue (Studi Kasus Kabupaten Pati).," Techno. Com, vol. 14, no. 4, pp. 272-280, 2015. S. H. Kusumadewi, "Fuzzy Multi-Attribute Decision Making (Fuzzy MADM)," Graha Ilmu Yogyakarta, 2006. 
V. C. Hardita, E. Utami, and E. T. Luthfi, "Sistem Pendukung Keputusan Pemilihan Sales Terbaik," Creat. Inf. Technol. J., vol. 5, no. 2, p. 138, 2019, doi: 10.24076/citec.2018v5i2.177. 